\title{
Interannual variability of tropospheric composition: the influence of changes in emissions, meteorology and clouds
}

\author{
A. Voulgarakis ${ }^{1, *}$, N. H. Savage ${ }^{2}$, O. Wild ${ }^{3}$, P. Braesicke ${ }^{1}$, P. J. Young ${ }^{1, * *}$, G. D. Carver ${ }^{1}$, and J. A. Pyle ${ }^{1}$ \\ ${ }^{1}$ Centre for Atmospheric Science, University of Cambridge, UK \\ ${ }^{2}$ Met Office, Exeter, UK \\ ${ }^{3}$ Lancaster Environment Centre, Lancaster University, UK \\ *now at: NASA Goddard Institute for Space Studies \& Columbia University, Center for Climate Systems Research, \\ New York, USA \\ ${ }^{* *}$ now at: NOAA Earth System Research Laboratory, Boulder, Colorado, USA
}

\begin{abstract}
We have run a chemistry transport model (CTM) to systematically examine the drivers of interannual variability of tropospheric composition during 1996-2000. This period was characterised by anomalous meteorological conditions associated with the strong El Niño of 1997-1998 and intense wildfires, which produced a large amount of pollution. On a global scale, changing meteorology (winds, temperatures, humidity and clouds) is found to be the most important factor driving interannual variability of $\mathrm{NO}_{2}$ and ozone on the timescales considered. Changes in stratospheretroposphere exchange, which are largely driven by meteorological variability, are found to play a particularly important role in driving ozone changes. The strong influence of emissions on $\mathrm{NO}_{2}$ and ozone interannual variability is largely confined to areas where intense biomass burning events occur. For $\mathrm{CO}$, interannual variability is almost solely driven by emission changes, while for $\mathrm{OH}$ meteorology dominates, with the radiative influence of clouds being a very strong contributor. Through a simple attribution analysis for 19962000 we conclude that changing cloudiness drives $25 \%$ of the interannual variability of $\mathrm{OH}$ over Europe by affecting shortwave radiation. Over Indonesia this figure is as high as $71 \%$. Changes in cloudiness contribute a small but nonnegligible amount (up to 6\%) to the interannual variability of ozone over Europe and Indonesia. This suggests that future assessments of trends in tropospheric oxidizing capacity should account for interannual variability in cloudiness, a factor neglected in many previous studies.
\end{abstract}

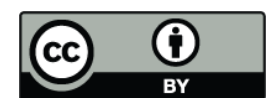

Correspondence to: A. Voulgarakis (avoulgarakis@giss.nasa.gov)

\section{Introduction}

Reactive tropospheric trace gases play an important role in the Earth system, influencing climate (methane $\left(\mathrm{CH}_{4}\right)$, ozone) and determining air quality (ozone, nitrogen oxides $\left(\mathrm{NO}_{\mathrm{x}}\right)$, volatile organic compounds). Their concentrations vary on a vast spatial and temporal scale, and characterising this variability is a major challenge. Studies examining trends focus on changes that occur on decadal timescales while studies examining interannual variability (IAV) focus on year-to-year variations. Here we focus on investigating the drivers of interannual variability of annual and seasonal mean concentrations of a variety of tracers.

One factor that can affect tropospheric composition significantly is year-to-year variations in anthropogenic emissions. The latter have changed during recent times in many parts of the globe: in east Asia, rapid industrial development has caused a dramatic increase of pollution (Richter et al., 2005), while in Western Europe, industrial/transport emissions slowly decreased during the 1990s due to control strategies (Fowler et al., 2001). Changes in biomass burning emissions $\left(\mathrm{NO}_{\mathrm{x}}, \mathrm{CO}\right.$, aerosols) from year to year can also affect tropospheric composition. An example is the fluctuations in wildfire-driven emissions over the Maritime Continent, depending on whether a year is characterized by El Niño or La Niña conditions (Hauglustaine et al., 1999).

Meteorology can also be very important in driving tropospheric composition IAV, but the extent of this influence is still an issue for exploration, with some useful contributions made in recent model studies (e.g. Dentener et al., 2003; Thouret et al., 2006; Szopa et al., 2007; Uno et al., 2007; Savage et al., 2008; Hess and Mahowald, 2009). Longrange transport events (Wild and Akimoto, 2001), which are

Published by Copernicus Publications on behalf of the European Geosciences Union. 
initiated by lifting of surface pollution by weather systems or deep convection, are meteorology-related and undergo large year-to-year changes. For example, transport of pollution from North America and Asia can cause increases in the concentrations of ozone and related species over Europe (Creilson et al., 2003; Pfister et al., 2004; Derwent et al., 2004; Auvray and Bey, 2005), while European pollution can impact either cleaner areas like the North Atlantic Ocean and Northern Africa (Duncan and Bey, 2004), or North America during anomalous transport events ( $\mathrm{Li}$ et al., 2002). Transpacific transport can also be very important, with Asian emissions impacting clean oceanic regions, or even North America, depending on the meteorology (Liu et al., 2005; Cooper et al., 2010). This influence is particularly strong during $\mathrm{El}$ Niño years.

Apart from changes in the winds (influencing transport processes), other meteorological variables that affect chemistry in a chemistry transport model (CTM) can vary strongly from year to year. Changes in humidity can affect the production of $\mathrm{OH}$, which in turn impacts the loss and the production of tropospheric ozone. $\mathrm{OH}$ variability also strongly affects the loss processes of methane, $\mathrm{CO}$, hydrocarbons and $\mathrm{NO}_{\mathrm{x}}$. On the other hand, variations in temperature and, in some cases, pressure may impact the reaction rates that determine the concentrations of various tracers. Finally, clouds can directly affect gas-phase tropospheric chemistry by decreasing shortwave radiation below them, and increasing it above them. This leads to important effects on photolysis and, through $J\left(\mathrm{O}^{1} D\right)$ modifications, on $\mathrm{OH}$ concentrations above and below clouds (especially in the boundary layer), with a variety of subsequent effects on ozone and its precursors (for more details see Tie et al. (2003); Liu et al. (2006); Voulgarakis et al. (2009b)). All these processes show strong interannual variability.

Extraordinary meteorological conditions, like exceptionally strong El Niño events (e.g. in 1997-1998) can lead to large composition anomalies, with, for example, elevated ozone over the western Pacific and decreased ozone over its eastern parts (Chandra et al., 1998; Sudo and Takahashi, 2001; Doherty et al., 2006). Results from the modelling study of Zeng and Pyle (2005) suggest that El Niño also has an impact on the amount of stratospheric ozone entering the troposphere through stratosphere-troposphere exchange (STE), and that through these changes even the composition of the extratropical troposphere is affected (also see Koumoutsaris et al. (2008)).

Recent model studies have examined the drivers of interannual variability of tropospheric trace gases such as $\mathrm{OH}$ (Dentener et al., 2003; Dalsoren and Isaksen, 2006), CO (Szopa et al., 2007) and $\mathrm{NO}_{2}$ (Uno et al., 2007; Savage et al., 2008), reaching a variety of useful conclusions. However, a systematic study a) involving more than one interdependent species, b) focusing on global as well as regional scales, and c) investigating the role of clouds independently in addition to meteorology and emissions, to our knowledge has not been presented so far. In particular, the radiative effect of clouds on chemistry (through photolysis) has commonly been neglected as a driver of either IAV or trends in previous studies.

In Sect. 2 we present the basic model features and the experimental set-up, and show that the model reasonably captures the interannual variability in pollution. Section 3 analyzes the drivers of IAV of global $\mathrm{NO}_{2}$ and ozone columns, while Sect. 4 quantitatively assesses the influence of emissions, meteorology and clouds on ozone, $\mathrm{CO}$ and $\mathrm{OH}$. Finally, the conclusions are included in Sect. 5.

\section{Model set-up and validation of its ability to capture interannual variability}

The model used for the experiments is the updated version of the $p$-TOMCAT tropospheric CTM described in Voulgarakis et al. (2009a). A detailed description of the ozone budget as calculated in the model is described in Voulgarakis et al. (2009b). The horizontal resolution is $2.8^{\circ} \times 2.8^{\circ}$ and there are 31 vertical levels extending from the surface to $10 \mathrm{hPa}$. Tropospheric chemistry for 63 trace species is simulated with the ASAD chemistry package (Carver et al., 1997), and photolysis rates are calculated using the Fast-JX photolysis scheme (Wild et al., 2000). Six-hourly meteorological data (winds, temperatures, humidities, cloud water contents) from the ECMWF analyses are used to drive the model. At the upper boundary, ozone, methane and $\mathrm{NO}_{\mathrm{y}}$ are prescribed with climatological values from the Cambridge 2-D-Model (Law and Pyle, 1993).

Annually and monthly-varying emissions for industry, transport, shipping and biomass burning come from the RETRO emissions database (Schultz, 2007). Biogenic emissions are taken from Müller (1992) and Lathière et al. (2006) and are not interannually varying. Lightning emissions of $\mathrm{NO}_{\mathrm{x}}$ are based on the parameterization of Price and Rind (1994) as implemented by Stockwell et al. (1999). The average lightning emission for the 1996-2000 period is $3.9 \mathrm{Tg}(\mathrm{N}) \mathrm{yr}^{-1}$. We use a fixed global annual 3-D field for methane produced from an earlier long-term integration (global burden: $4760 \mathrm{Tg}$ methane). Year-to-year variations in global annual total emissions for each species are shown in Table 1 for three different latitude zones. For all species, the highest global emission rates occurred in 1997 in the tropics and in 1998 in the northern extratropics. These two years were characterized by intense wildfire events in the tropics (1997) and in boreal regions (1998), which influenced global tropospheric chemistry for many months. In the southern extratropics the highest emissions are in 1998, but IAV in the emissions is generally small.

The analysis is based on the results of three model integrations from 1996 to 2000 (the approach follows Savage et al. (2008)): a) BASE, in which all variables vary from year to year; b) EmFix, in which the surface emissions of all species 
Table 1. Total annual surface emissions (in $\mathrm{Tg} \mathrm{yr}^{-1}$ ) for all species emitted in $p$-TOMCAT for the northern extratropics $\left(20^{\circ} \mathrm{N}-90^{\circ} \mathrm{N}\right)$, the tropics $\left(20^{\circ} \mathrm{S}-20^{\circ} \mathrm{N}\right)$ and the southern extratropics $\left(90^{\circ} \mathrm{S}-20^{\circ} \mathrm{S}\right)$. Lightning and aircraft $\mathrm{NO}_{\mathrm{x}}$ emissions are not included here.

\begin{tabular}{|c|c|c|c|c|c|}
\hline Species /Year & 1996 & 1997 & 1998 & 1999 & 2000 \\
\hline \multicolumn{6}{|l|}{ NORTHERN EXTRATROPICS } \\
\hline $\mathrm{NO}_{\mathrm{x}}$ & 86.3 & 84.1 & 86.3 & 84.5 & 86.5 \\
\hline $\mathrm{CO}$ & 489.7 & 441.7 & 509.0 & 439.3 & 445.2 \\
\hline Ethane & 4.9 & 4.6 & 5.1 & 4.7 & 4.8 \\
\hline Propane and higher alkanes & 27.3 & 26.6 & 26.1 & 26.2 & 26.4 \\
\hline Isoprene & 115.3 & 115.3 & 115.3 & 115.3 & 115.3 \\
\hline Formaldehyde & 10.8 & 10.2 & 11.4 & 10.3 & 10.4 \\
\hline Acetaldehyde & 11.7 & 11.5 & 12.0 & 11.5 & 11.6 \\
\hline Acetone & 29.4 & 29.3 & 29.6 & 29.1 & 29.1 \\
\hline \multicolumn{6}{|l|}{ TROPICS } \\
\hline $\mathrm{NO}_{\mathrm{X}}$ & 40.3 & 46.5 & 44.0 & 40.7 & 41.8 \\
\hline $\mathrm{CO}$ & 482.6 & 719.2 & 585.2 & 493.5 & 504.2 \\
\hline Ethane & 3.9 & 6.5 & 4.8 & 4.0 & 4.0 \\
\hline Propane and higher alkanes & 6.8 & 9.1 & 7.5 & 6.9 & 6.9 \\
\hline Isoprene & 379.8 & 379.8 & 379.8 & 379.8 & 379.8 \\
\hline Formaldehyde & 18.6 & 21.3 & 19.8 & 18.7 & 18.8 \\
\hline Acetaldehyde & 19.1 & 20.1 & 19.7 & 19.1 & 19.2 \\
\hline Acetone & 43.9 & 45.5 & 44.7 & 44.0 & 44.1 \\
\hline \multicolumn{6}{|l|}{ SOUTHERN EXTRATROPICS } \\
\hline $\mathrm{NO}_{\mathrm{x}}$ & 9.3 & 9.3 & 10.0 & 9.6 & 9.6 \\
\hline $\mathrm{CO}$ & 60.2 & 61.1 & 73.8 & 66.0 & 63.7 \\
\hline Ethane & 0.7 & 0.7 & 0.8 & 0.8 & 0.8 \\
\hline Propane and higher alkanes & 1.9 & 1.9 & 1.9 & 1.8 & 1.8 \\
\hline Isoprene & 27.0 & 27.0 & 27.0 & 27.0 & 27.0 \\
\hline Formaldehyde & 1.5 & 1.5 & 1.6 & 1.5 & 1.5 \\
\hline Acetaldehyde & 1.5 & 1.5 & 1.6 & 1.6 & 1.5 \\
\hline Acetone & 3.6 & 3.6 & 3.7 & 3.6 & 3.6 \\
\hline
\end{tabular}

Table 2. Runs conducted for this study and how they differ. Interannually-varying fields are denoted with "1996-2000" and fields without interannual variation are labelled "1996". Note that "Clouds" are a subset of "Meteorology" in the current approach, meaning that in the case that meteorology is fixed to 1996 values (MetFix), clouds are kept fixed as well.

\begin{tabular}{lccc}
\hline & Emissions & Meteorology & Clouds \\
\hline BASE & $1996-2000$ & $1996-2000$ & $1996-2000$ \\
EmFix & 1996 & $1996-2000$ & $1996-2000$ \\
MetFix & $1996-2000$ & 1996 & 1996 \\
CldFix & $1996-2000$ & $1996-2000$ (except clouds) & 1996 \\
\hline
\end{tabular}

vary seasonally but not interannually (fixed at 1996 values; note that lightning emissions vary interannually here as they are meteorology driven); and c) MetFix, in which the 1996 meteorology (temperatures, winds, humidity and clouds) is repeated for each year (still varying 6-hourly). The model was run from June 1995 to December 1995 for spin-up. In
Table 2 we summarise these runs. CldFix, a run like BASE but with clouds only fixed at 1996 values, is analyzed in Section 4.

A detailed evaluation, presented in Voulgarakis et al. (2009a), showed that the model is capable of capturing ozone and $\mathrm{CO}$ seasonal cycles well, and that the concentrations of these tracers at various sites compare well with observations. Notable underestimates were found in the Northern Hemisphere for surface $\mathrm{CO}$ and overestimates in the upper troposphere for ozone. These features are relatively common in current global models (Shindell et al., 2006; Stevenson et al., 2006).

Here, we further assess how well the model captures observed interannual variations of tracers during the period of interest. In Fig. 1, we show percentage surface $\mathrm{CO}$ seasonal mean concentration differences from the 5-year mean as calculated from our model and as observed. The observations are from the NOAA-ESRL-GMD network (see Novelli et al. (2003)). Figure 2 shows the same comparison for ozone, using data from the WMO World Data Center for Greenhouse Gases (WDCGG) (http://gaw.kishou.go.jp/ wdegg.html) and from stations of the NOAA-ESRL-GMD 

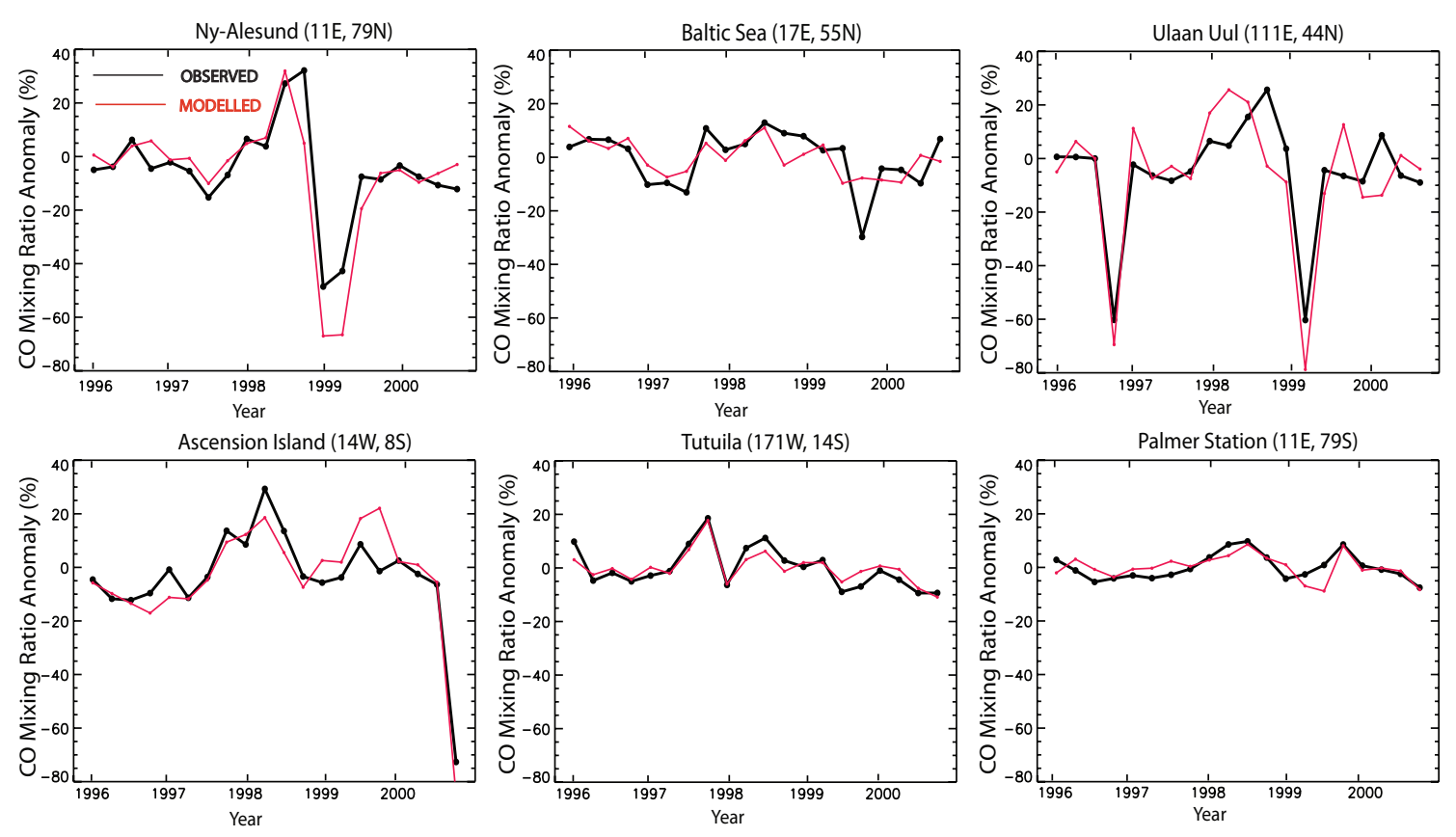

Fig. 1. Percentage surface CO seasonal mean concentration differences from the 5-year mean as calculated from our model (BASE run; red) and from observations (black). Observational data come from the NOAA-ESRL-GMD network. For every year there are four points, each one corresponding to one season: January-February-March, April-May-June, July-August-September, October-November-December).
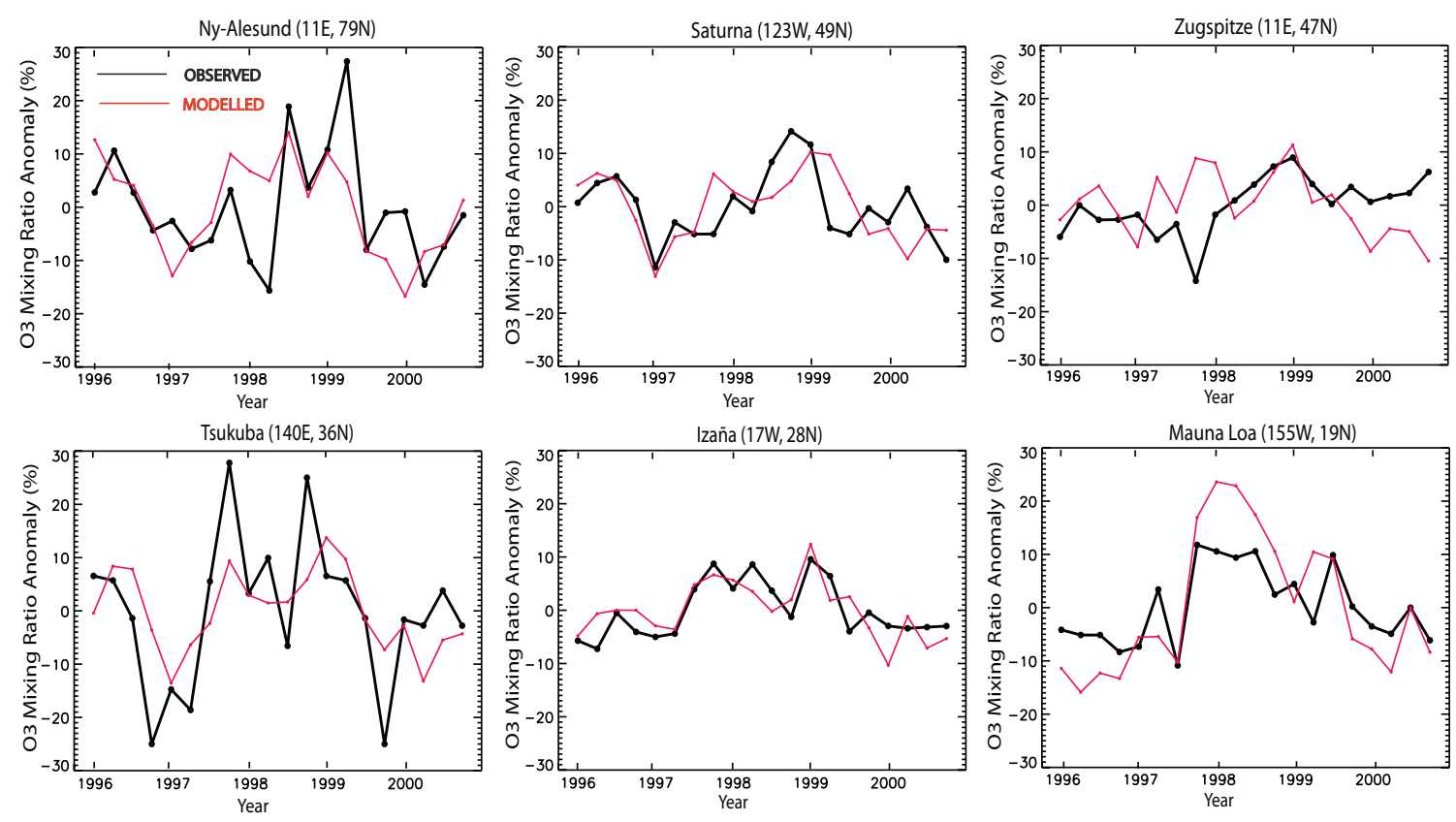

Fig. 2. Percentage surface ozone seasonal mean concentration differences from the 5-year mean as calculated from our model (BASE run; red) and from observations (black). Observational data come from the WDCGG, except for Mauna Loa, for which data are from the NOAAESRL-GMD network. For every year there are four points, each one corresponding to one season: January-February-March, April-May-June, July-August-September, October-November-December). 

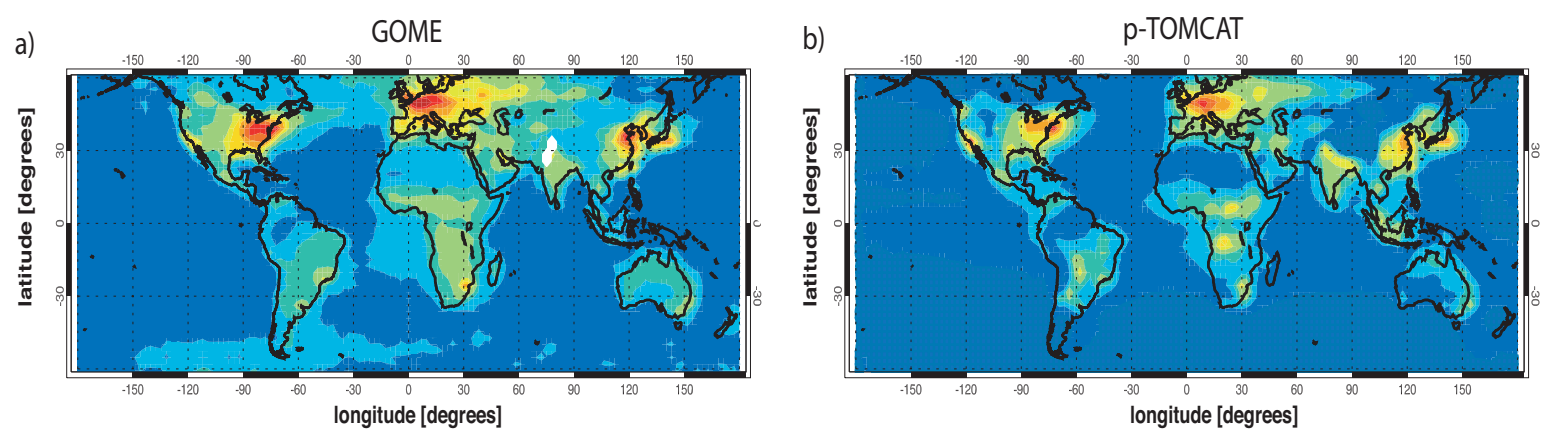

Mean Total Tropospheric $\mathrm{NO}_{2}$ column $\left(10^{15}\right.$ molecules $\left.\mathrm{cm}^{-2}\right)$
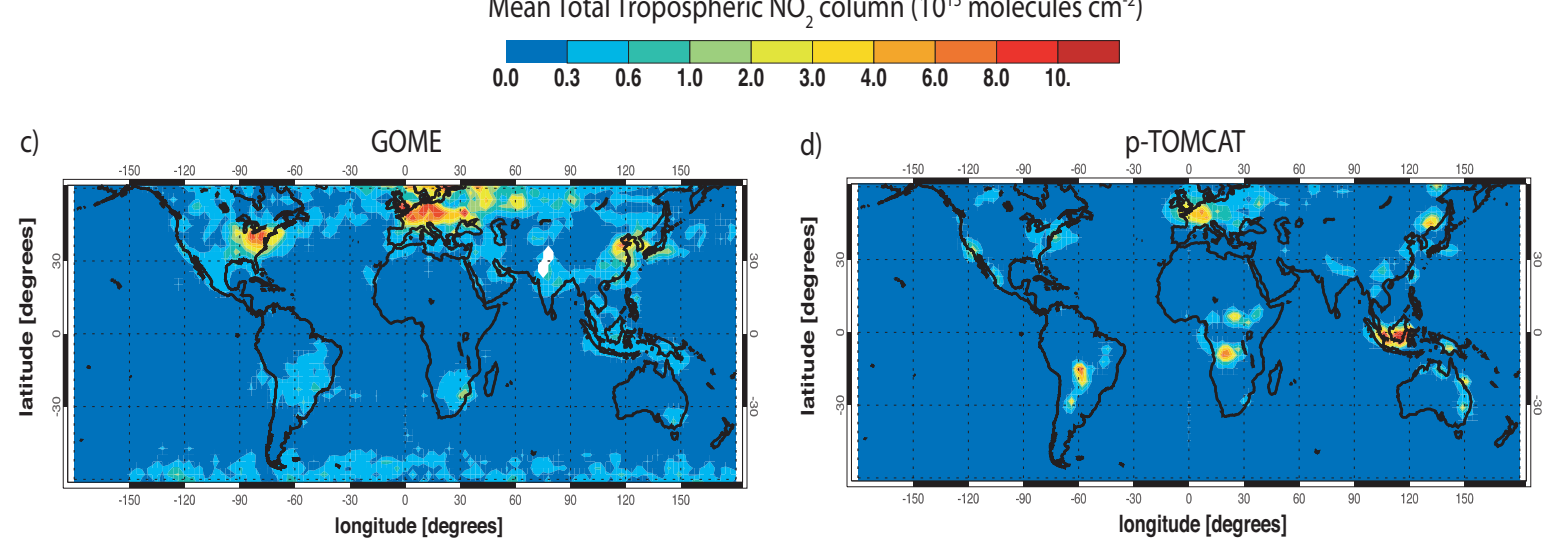

Total Tropospheric $\mathrm{NO}_{2}$ column Standard Deviation $\left(10^{15}\right.$ molecules $\left.\mathrm{cm}^{-2}\right)$

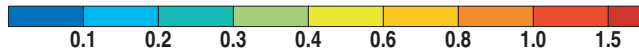

Fig. 3. Comparison of (a, b) annual 5-year mean $p$-TOMCAT tropospheric $\mathrm{NO}_{2}$ columns and (c, d) their standard deviation, with GOME observations. The white area over north India denotes a lack of observations during the 1996-2000 period.

network (see Oltmans and Levy II (1994)). The sites have been chosen to represent a variety of different regions around the globe.

It is clear that the model has good skill in simulating interannual variability for these two species. For $\mathrm{CO}$, the agreement between modelled and measured differences is very good, with the widespread anomaly of 1997-1998 evident in all the sites that we examine. The only apparent discrepancy is seen at Ulaan Uul in 1997 where the CO increase is found about 6 months earlier in the model than in the observations. For ozone, which is more sensitive to chemical processing than $\mathrm{CO}$, there are more differences in the details of the variability, but the main features in the observed variability, such as the late-1997/early-1999 anomaly, are clearly evident in the model.

In Fig. 3 we present a comparison of global modelled $\mathrm{NO}_{2}$ to observations from the GOME satellite instrument for 1996-2000. We compare 5-year mean columns (a, b) and standard deviations (c, d) to provide an assessment of how well the model captures the IAV of global pollution. Sampling of model output data (at 10:45 LT, the GOME overpass time) and post-processing of satellite retrievals is performed as described in Savage et al. (2008), and the annual averaging helps to remove random errors in the measurements.

The model generally captures the distribution of $\mathrm{NO}_{2}$ tropospheric column maxima around the globe quite well, and this is also true on a seasonal basis (not shown). The model underestimates total $\mathrm{NO}_{2}$ in the Northern Hemisphere, especially over industrialized regions (northeast America, Western Europe, East Asia), suggesting that the $\mathrm{NO}_{2}$ lifetime may be too short in the model. However, there is an overestimation of the maxima related to biomass burning in the tropics (Indonesia, central Africa), which is most likely related to too high $\mathrm{NO}_{\mathrm{x}}$ emissions provided by RETRO for this region during the 1997 wildfire events. Over South America and central/southern Africa the observed columns are more spatially widespread than those in the model runs, where maxima occur closer to source regions. This negative model bias over industrialized regions and positive bias over biomass burning regions are also evident for most of the models involved in the intercomparison performed by van Noije et al. (2006). They did not reach a clear conclusion as to what causes these discrepancies. 
The absolute standard deviations of the $\mathrm{NO}_{2}$ column (Fig. 1c and d) show that regions of strong IAV are captured reasonably well, but the amplitude of year-to-year variations is underestimated by the model over Northern Hemispheric industrialized regions. For the areas where strong biomass burning events occur IAV is overestimated. These differences between measured and modelled standard deviations could be related to uncertainties in the column retrievals or to uncertainties in the modelled IAV. Examining the standard deviation normalized to the 5-year mean (not shown), we find that underestimated variability over industrialized regions shown in Fig. 3 is not caused by the underestimation of $\mathrm{NO}_{2}$ columns. Possible reasons for these discrepancies include a) lack of IAV in aerosol concentrations driving $\mathrm{NO}_{2}$ loss in the model and b) no representation of year-to-year variations in methane and stratospheric ozone in the runs analyzed for the current study.

We conclude that many of the general features of pollution variability are captured well by the CTM, and we next analyze the results of sensitivity experiments examining the drivers of IAV on global and regional scales.

\section{Emissions and meteorology: their influence on $\mathrm{NO}_{2}$ and ozone interannual variability}

\subsection{Tropospheric $\mathrm{NO}_{2}$ column interannual variability}

Figure 4 shows the 1996-2000 differences from the 5-year mean of tropospheric $\mathrm{NO}_{2}$ columns for all individual years. The BASE run describes the overall IAV. In the idealized case that these differences were entirely driven by emission changes, the values on the plots for the EmFix run would all be zero, while the ones for the MetFix run would look identical to the ones for BASE. We focus on percentage differences, as they better highlight the effect of emissions and meteorology both over polluted and unpolluted regions.

It is clear from Fig. 4 that the BASE and EmFix differences look very similar for corresponding years, while the ones for MetFix differ, with deviations from the 5-year mean being generally closer to $0 \%$. This indicates that IAV in meteorology is far more important as a driver for changes in $\mathrm{NO}_{2}$ abundances than emissions over most of the globe on these timescales. The only regions where IAV is captured with fixed meteorology are associated with important biomass burning events. The 1997 events in Indonesia (Hauglustaine et al., 1999) and 1998 in Siberia/Canada (Spichtinger et al., 2004) correspondingly cause large differences from the 5year mean (up to $+240 \%$ in Indonesia and $+100 \%$ in Siberia) which dominate the variability over these regions. To a lesser extent, fires over central Africa/Amazonia (mainly 1998) and the Iberian peninsula (2000) appear to drive much of $\mathrm{NO}_{2}$ IAV over these areas. As discussed in Sect. 2, the effect of fires over tropical regions may be overestimated in the model, but the dominant role of emissions in controlling the variability is expected to be represented well.

Changes in meteorology drive the IAV of $\mathrm{NO}_{2}$ in a number of regions around the globe. For example, without taking into account changes in meteorology, the $\mathrm{NO}_{2}$ pollution caused by the 1997 wildfires would have been strictly confined to the Indonesian region (MetFix plot for 1997). When we neglect IAV in emissions (EmFix plot for 1997), the anomalous 1997 wildfire emissions are not taken into account, and $\mathrm{NO}_{2}$ is closer to average or even below average over Borneo and Sumatra. However, there are still large increases in the 1997 columns in the surrounding areas (Indian Ocean, central west Pacific). This indicates that areas surrounding Indonesia, where other studies (e.g. Duncan et al., 2003) have found that pollution from the 1997 wildfires was transported to, would have experienced $\mathrm{NO}_{2}$ increases in 1997 even without the occurrence of the anomalous biomass burning events. Normal emissions over Indonesia would have been transported large distances due to the anomalous circulation. We note that much of the $\mathrm{NO}_{2}$ transport occurs through peroxyacetyl nitrate (PAN), a major reservoir of $\mathrm{NO}_{\mathrm{x}}$, which can be transported and release $\mathrm{NO}_{2}$ at a large distance from the source region (Moxim et al., 1996).

Apart from the surface emissions effect, one other reason why $1997 \mathrm{NO}_{2}$ columns over Indonesia are lower in MetFix than in BASE may be that suppressed convection could have led to lower lightning activity in the area. In Fig. 5a we show the 1996-2000 $500 \mathrm{hPa}$ mean radon concentration differences from the 5-year mean over Indonesia in the BASE run. Radon has a short lifetime of around 5.5 days, is emitted predominantly over land and its tropospheric distribution depends strongly on horizontal and vertical transport (Jacob et al., 1997). Increased values of radon in the middle troposphere indicate higher convection. In 1997, radon abundances are around $8 \%$ less than average, which shows that Indonesia was a region of suppressed convection during this year. In Fig. $5 \mathrm{~b}$ we show the differences from the 5-year mean of the annual total lightning $\mathrm{NO}_{\mathrm{x}}$ emission over Indonesia in the BASE run. It is clear that 1997 is a year with much (close to $15 \%$ ) lower than average lightning $\mathrm{NO}_{\mathrm{x}}$ emissions. However, this negative effect on the $\mathrm{NO}_{\mathrm{x}}$ columns is masked by the strong positive effects from the wildfire emissions in the BASE run. Similarly, in 1996, when lightning $\mathrm{NO}_{\mathrm{x}}$ emissions are much greater than average, $\mathrm{NO}_{2}$ columns are low in the model, because surface emissions are low.

El Niño-associated dryness, another meteorological factor (Chandra et al., 1998), could also have played a role in increasing $\mathrm{NO}_{2}$ columns, as a reduced abundance of $\mathrm{OH}$ would increase the lifetime of $\mathrm{NO}_{\mathrm{x}}$. In our model, decreases in surface water vapor concentrations over the western Pacific are up to $8 \%$ while increases over the central and eastern Pacific are up to $12 \%$ (see Fig. 5c). However, as shown later, 1997 was a year with high OH levels over Indonesia due to reduced cloud cover, so dryness cannot have been the main driving factor. Decreased wet deposition of $\mathrm{HNO}_{3}$, a loss 


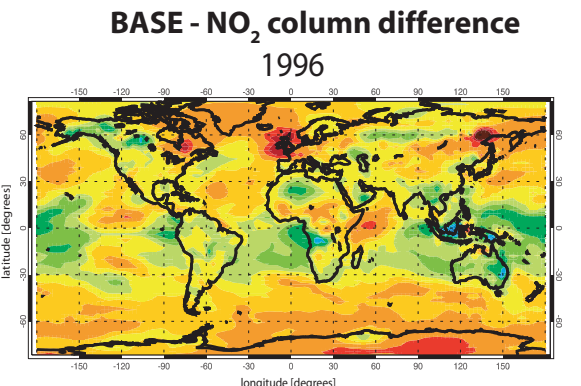

1997

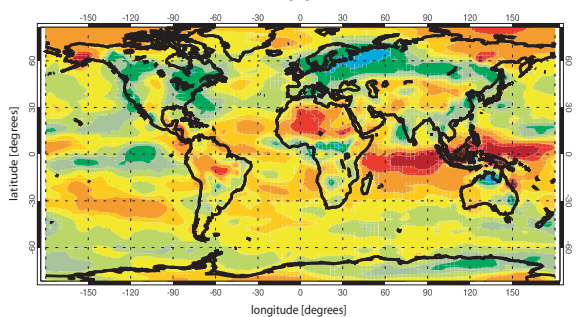

1998

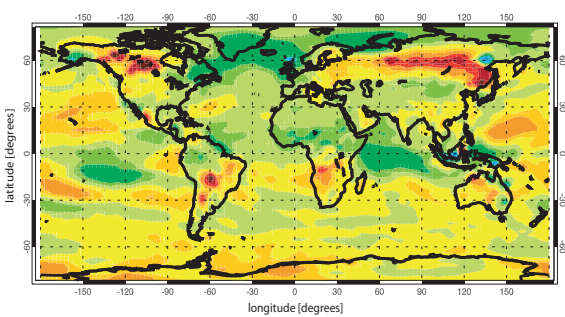

1999

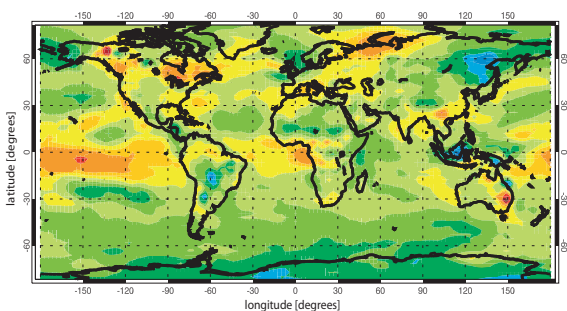

2000

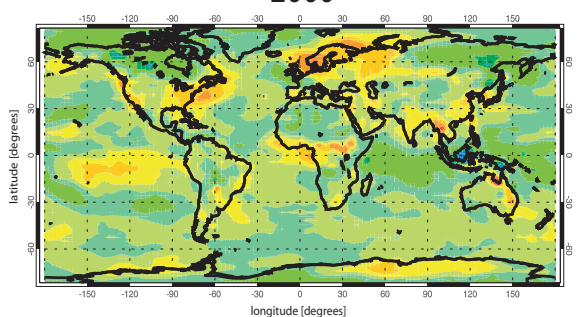

$-50 . \quad-30 . \quad-20$.
EmFix - $\mathrm{NO}_{2}$ column difference 1996

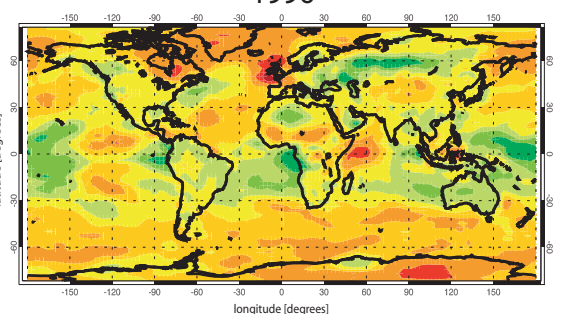

1997

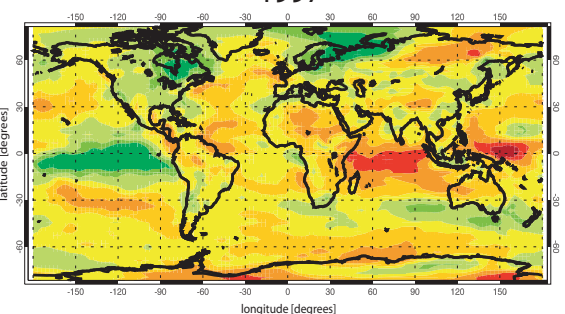

1998

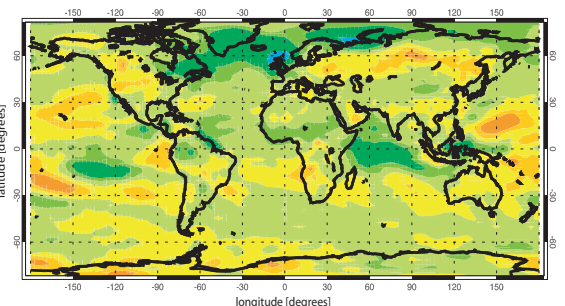

1999

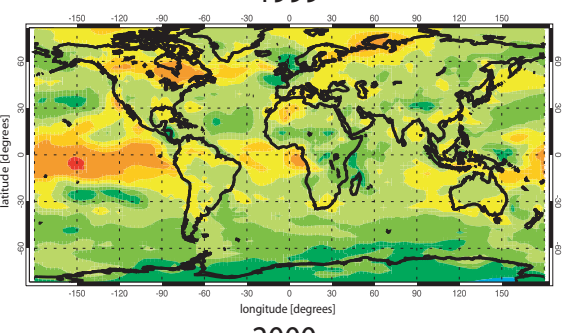

2000

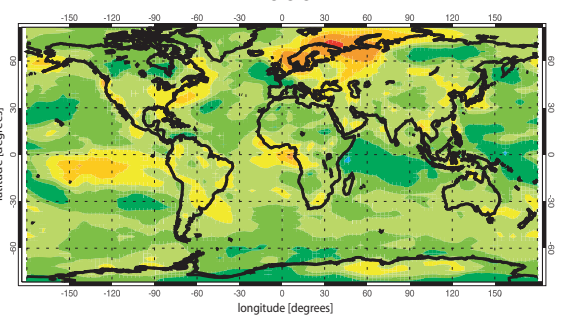

MetFix $-\mathrm{NO}_{2}$ column difference 1996

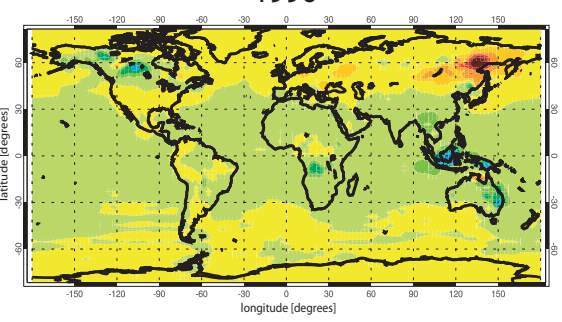

1997

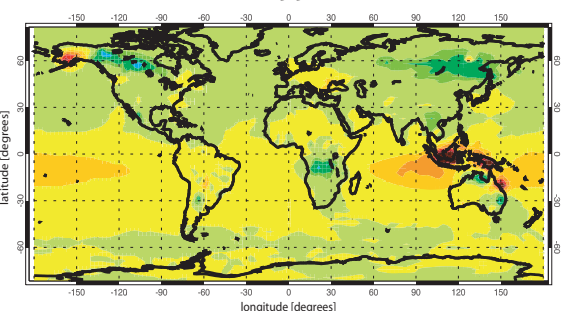

1998

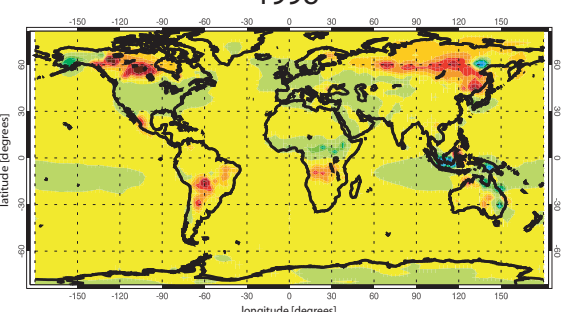

1999

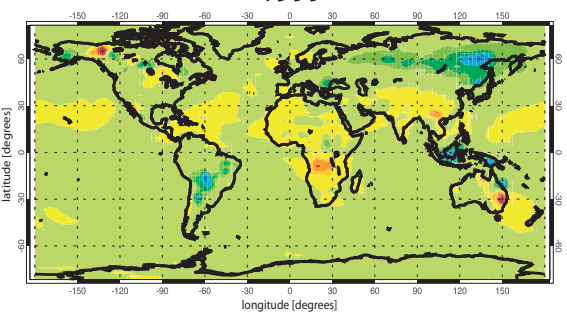

2000

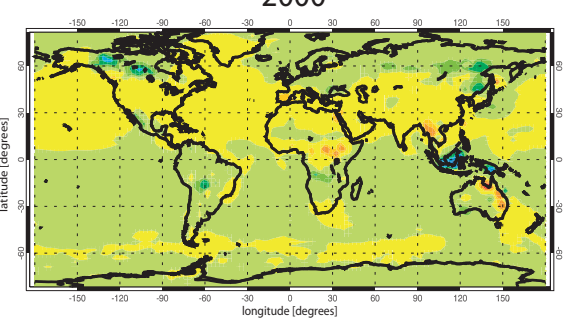

50.

(\%)

Fig. 4. Percentage differences between tropospheric $\mathrm{NO}_{2}$ columns for each year and the 5-year (1996-2000) mean. Each column corresponds to one sensitivity run (BASE, EmFix, MetFix). The tropopause was assumed to follow the $380 \mathrm{~K}$ isentropic surface in the tropics and the 3.5 PVU surface in the extratropics. 

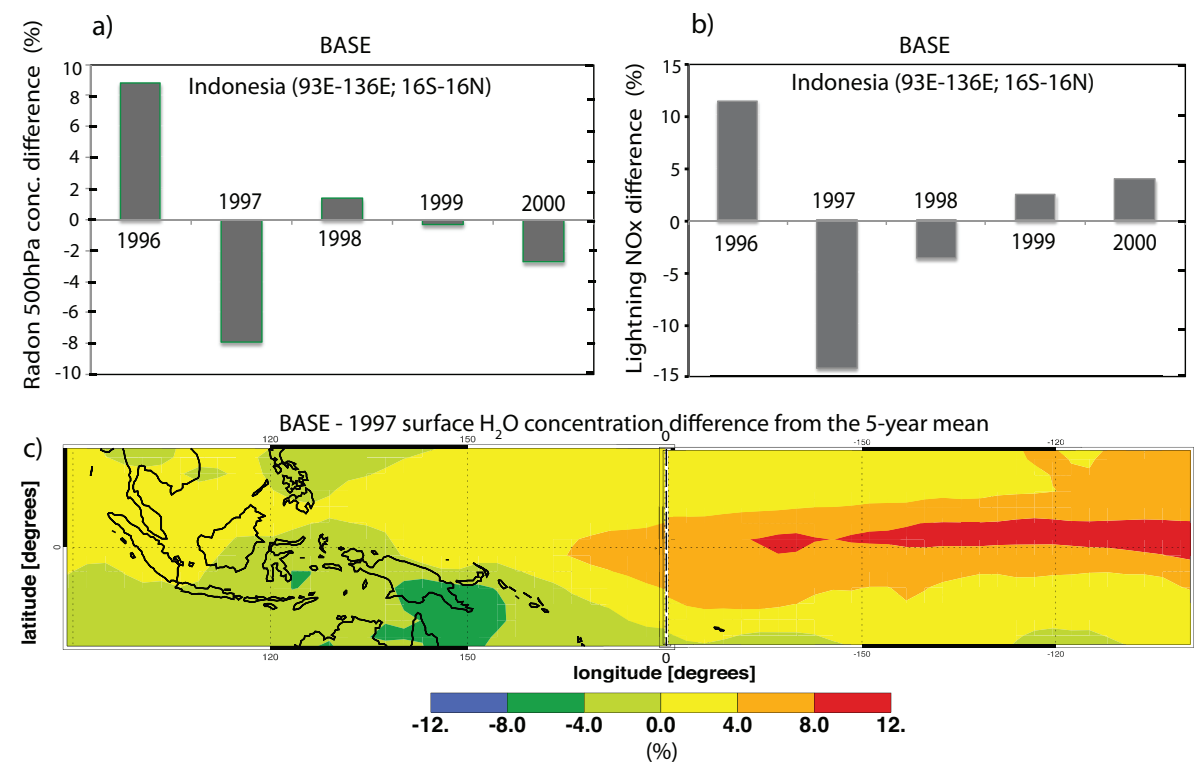

Fig. 5. Tropical Pacific meteorology: (a) 1996-2000 percentage annual 500 hPa mean radon concentration differences from the 5-year mean over Indonesia in the BASE run; (b) 1996-2000 percentage annual total lightning $\mathrm{NO}_{\mathrm{x}}$ emission differences from the 5-year mean over Indonesia in the BASE run; (c) 1997 percentage annual surface water vapor concentration differences from the 5-year mean over the tropical Pacific in the BASE run.

process for $\mathrm{NO}_{\mathrm{x}}$, also plays some role in boosting the positive signals over the Indian Ocean and western Pacific.

Apart from the Maritime Continent, other continental regions where meteorological processes appear to have driven significant $\mathrm{NO}_{2}$ column increases include the British Isles in 1996 (as also seen by Savage et al., 2008), North Africa in 1997 and northeastern Europe in 2000. In all these cases, deviations from the 5-year mean could be related to increased lightning activity (especially in the tropics), humidity, cloud optical depths or anomalous transport processes in the corresponding years. We calculated the anomalies of radon concentrations (not shown) and found that they are strongly correlated with the features found for $\mathrm{NO}_{2}$ over the same areas, implying that transport was the major driver of the $\mathrm{NO}_{2}$ changes during the period of interest.

There are continental regions where $\mathrm{NO}_{2}$ columns are notably lower than average in particular years, for example over most of Europe in 1997, northeast America in 1997, far-East Asia in 1999 and central South America in 1999. Following the approach above, we find that in the former two cases (Europe, northeast America) the lower $\mathrm{NO}_{\mathrm{x}}$ columns are explained by meteorology (transport) changes, while for the latter two cases (Asia, South America) emission anomalies are the main driver.

Note that the changes in meteorology are almost entirely responsible for year-to-year $\mathrm{NO}_{2}$ variability over the oceans, while over land the emission changes also appear to play some role (though in general smaller than that of meteorological changes). The fact that the oceans are areas with low
$\mathrm{NO}_{2}$ abundance (see Fig. 3) does not diminish the importance of this conclusion, since in $\mathrm{NO}_{\mathrm{x}}$-limited environments even small changes in $\mathrm{NO}_{2}$ concentrations can have a significant effect on other tracer budgets (e.g. for ozone). IAV driven by shipping emissions is not detectable, but it is likely that any related variability is masked by the effect of biomass burning plumes transported over the oceans.

\subsection{Tropospheric ozone column interannual variability}

Figure 6 shows the differences between each year's tropospheric ozone columns and the 5-year mean. The maximum differences for ozone are smaller than for $\mathrm{NO}_{2}$ (maximum $+36 \%$ over Indonesia in 1997 and around $+20 \%$ over northern high latitudes in 1998). A common feature of Figs. 4 and 6 is that the BASE and EmFix plots again look similar, implying that changing meteorology was the most important driver of tropospheric ozone IAV during this 5-year period. The comparison between these figures (BASE run; left column) also shows that, although there are some similarities in the spatial patterns of $\mathrm{NO}_{2}$ and ozone column differences (e.g. over Indonesia in 1997), generally the patterns are quite different. This is because ozone has a much longer lifetime than $\mathrm{NO}_{2}$ and its variability is affected by different processes, including anomalies in STE which can have large hemispheric impacts and can mask more local effects which are evident in $\mathrm{NO}_{2}$ patterns.

The ozone increases in the tropics in 1997 are driven both by the intense biomass burning events over Indonesia 


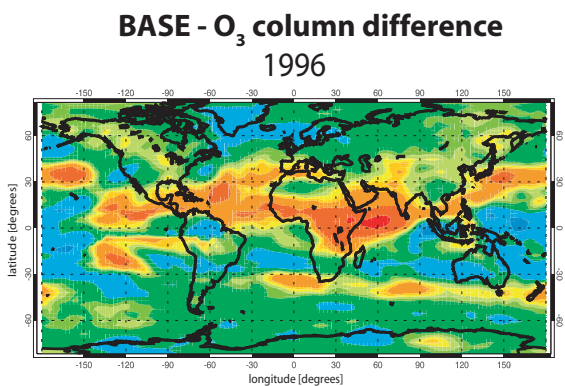

1997

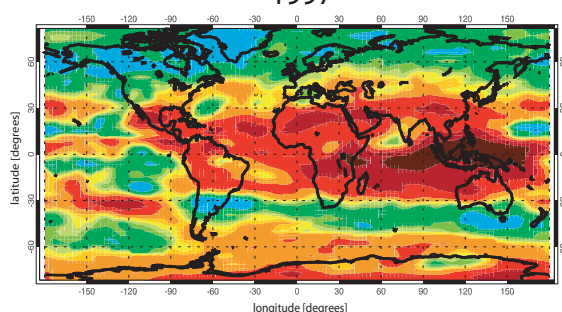

1998

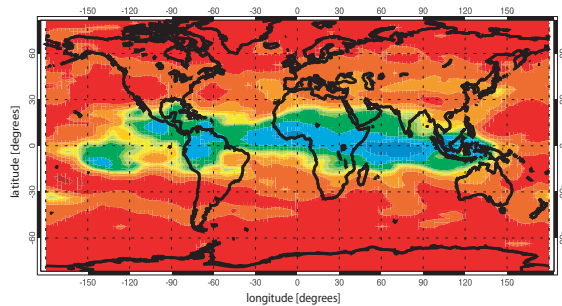

1999

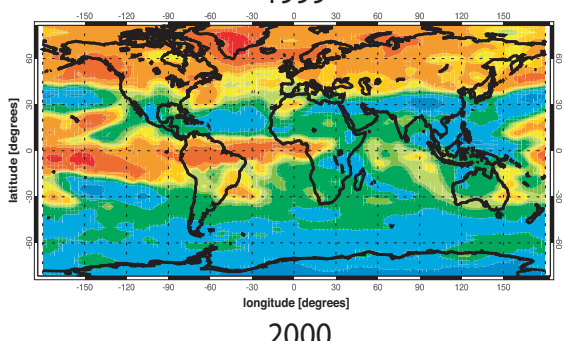

2000

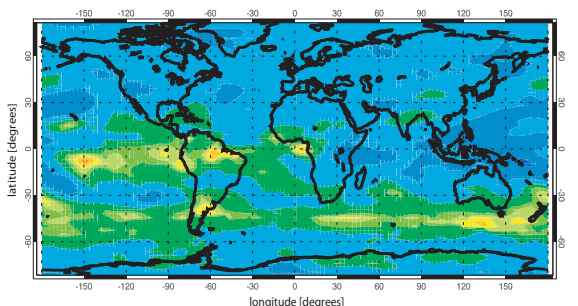

$-20 . \quad-10$.

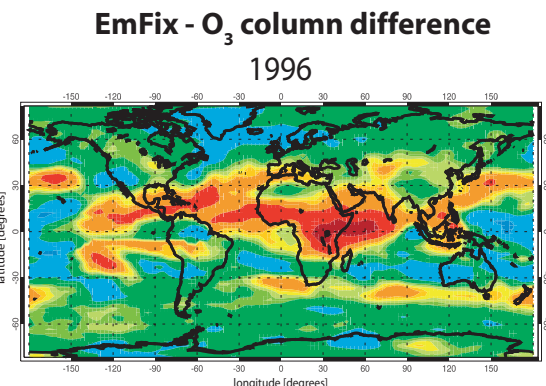

1997

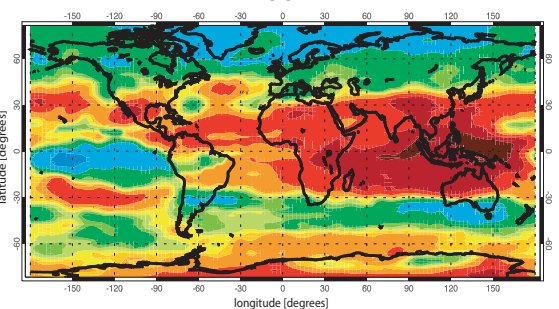

1998

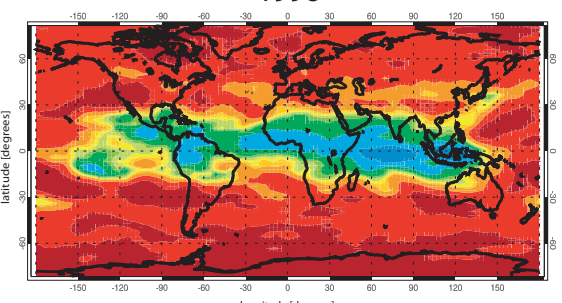

1999

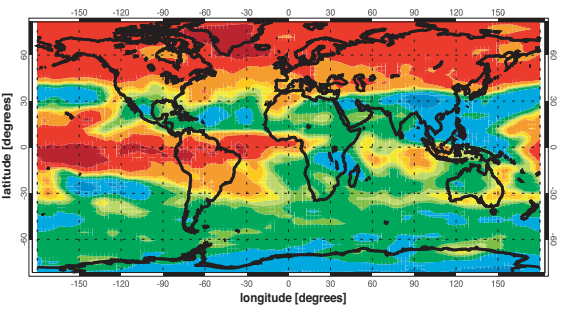

2000

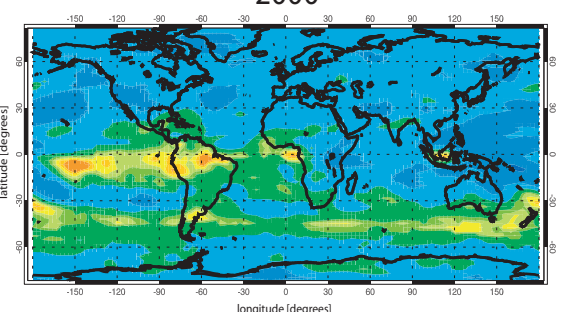

$-1.0 \quad 0.0$

(\%)

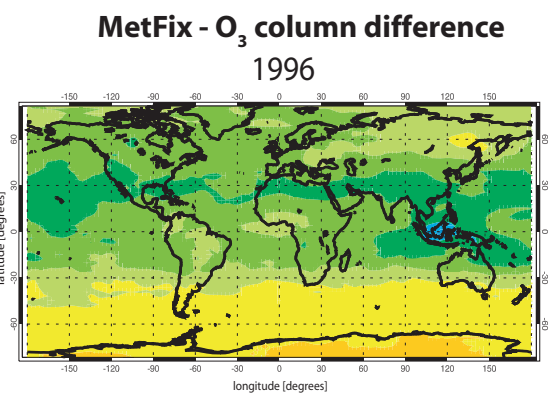

1997

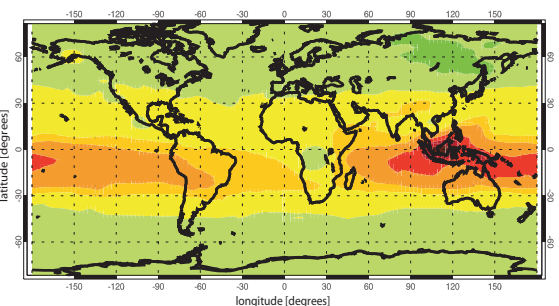

1998

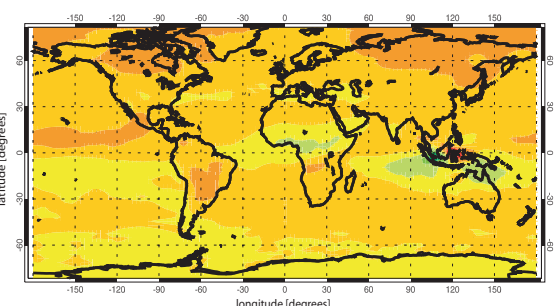

1999

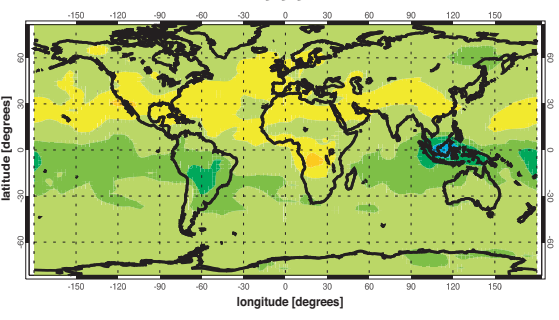

2000

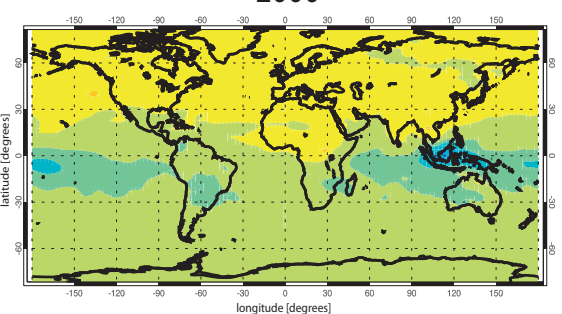

5.020.

Fig. 6. Percentage differences between tropospheric ozone columns for each year and the 5-year (1996-2000) mean. Each column corresponds to one sensitivity run (BASE, EmFix, MetFix). The tropopause was assumed to follow the $380 \mathrm{~K}$ isentropic surface in the tropics and the 3.5 PVU surface in the extratropics. 
(increase of precursors) and by the favourable meteorological situation related to El Niño: a) suppressed convection and downward motion which favour the downward transport of ozone-rich upper tropospheric air throughout the troposphere, and b) dryness which leads to decreased ozone loss by the $\mathrm{O}^{1} \mathrm{D}+\mathrm{H}_{2} \mathrm{O}$ reaction, over a large area centred around Indonesia. Note that if we had included interannually varying biogenic emissions, the increases in ozone over Indonesia in 1997 could have been larger, due to higher isoprene concentrations resulting from higher temperatures during El-Niño. However, a recent model experiment by Telford et al. (2009) examining the effects of the Mount Pinatubo eruption and the ealry-1990s El-Niño event suggests that ozone columns were only minorly affected by the effect of these perturbations on isoprene emissions. Furthermore, they found that interannual variability of isoprene emissions during the period of study was smaller than the uncertainty. We note though that the ealry-1990s El-Niño was not as intense as the late-1990s event, so a more detailed experiment is needed for the effect of isoprene to be investigated in the case that we examine.

The ozone pollution resulting from the wildfires was transported large distances from the sources. The only tropical area where ozone decreased in 1997 is the central/eastern Pacific where conditions are opposite to those found over the western Pacific. When fixing meteorology to 1996 values (MetFix), this feature disappears and increases are found in almost all tropical areas, excluding central Africa, possibly due to lower than average biomass burning emissions in 1997. However, the positive differences with MetFix are smaller in magnitude than with the other two runs; the only region where they are larger than $+5 \%$ is over and around Indonesia. Thus, while the IAV in emissions alone would cause some ozone increases, it is the meteorology which makes this more than a regional feature. Meteorology related to El Niño is the main driver of the effects seen in the tropics, and especially over the Pacific, while over the extratropics the meteorological influence of El Niño is not expected to have had any influence as early as in 1997.

In 1998, large positive differences from the 5-year mean (up to 20\%) are seen in all the extratropical areas, almost symmetrically centred around the tropics, where negative differences occur. The large boreal fires which occurred during that year and, to a smaller extent, the high fire activity in South America caused large increases in the amount of ozone precursors in the troposphere, partly causing the increases in extratropical ozone in this year. Also, the impact of tropical pollution produced in 1997 is expected to have a signal in the extratropics for several months, especially through the longrange transport of long-lived precursors (e.g., CO, see Duncan et al., 2003). However, with emissions at 1996 values (EmFix), all the features of the BASE plot for 1998 are preserved, with just a small reduction in the differences. In contrast, with fixed meteorology (MetFix), smaller, almost globally distributed differences from the 5-year mean are found for this year, with maxima of $2-5 \%$ located around the main biomass burning regions. Anomalous emissions only cause a small fraction of this year's anomaly seen in the extratropics.

The fact that the large extratropical positive deviations from the 5-year mean in 1998 are ubiquitous indicates that long-range transport within the mid-latitude troposphere is probably not the cause of the extratropical ozone increases (we would expect to see more spatial inhomogeneity if this was the case). Also, large increases are seen even for the southern extratropics where pollution sources are much less than at northern mid/high latitudes, again suggesting that long-range transport within the troposphere is not the main reason for ozone increases. Zeng and Pyle (2005) suggested that 1998 was a year of very high STE in the extratropics associated with high SST anomalies in the Pacific (El Niño) a few months earlier. This transport-related process is more likely to have caused the large positive deviations of ozone in the extratropics.

After examining the IAV of tropopause heights around the globe for the 1996-2000 period we note that the main features of Fig. 6 are not driven by changes in the total mass of air in the calculated tropospheric columns.

We have so far put more emphasis on the influence of transport on extratropical IAV when examining the effect of meteorology. However, other meteorological variables may have an influence, and the most important of these are humidity and cloud optical depth. Water vapor can increase loss of ozone (via $\mathrm{O}^{1} \mathrm{D}+\mathrm{H}_{2} \mathrm{O}$ ) but can also enhance the production of peroxy radicals which drive ozone production. However, there were no large hemispheric-scale increases in water vapour in 1998 in the model. We therefore examine the role of clouds in determining IAV of ozone in the next section, both for an extratropical and for a tropical region.

\section{Quantitative analysis of the role of emissions, meteo- rology and clouds}

Clouds play an important role in altering photochemical processes by modifying solar radiation throughout the tropospheric column. To our knowledge, there have been no previous studies assessing the role of clouds in the IAV of global tropospheric composition. Here we separate the shortwave radiative effect of clouds from other aspects of meteorological variability by conducting an additional model run. In this run, CldFix, 6-hourly varying 3-D cloud optical depths for 1996 are used throughout the 1996-2000 period; everything else varies as in BASE. Note that "clouds" are a subset of "meteorology" in the current approach, meaning that in the case that meteorology is fixed to 1996 values (MetFix), clouds are kept fixed as well. Deviations of the tracer abundances from the 5-year mean are compared to those seen when fixing the meteorology or the emissions to 1996 conditions. 


\subsection{Analysis of global ozone IAV drivers}

Figure 7 shows the difference in each year's ozone burden from the 5-year mean. It also shows the percentage of variability which is explained by each one of the factors separately, calculated using a simplified attribution approach based on Szopa et al. (2007). The 5-year anomalies for each run were averaged and then divided by the average anomaly for the BASE run in order to determine by how much the variability is reduced when each field is fixed at 1996 values. By subtracting this percentage from 100, the variability explained by each individual factor can be quantified. The equation used is the following:

$P=\left[1-\frac{\frac{1}{N} \sum_{i=0}^{N}\left|X(i)_{S}-\overline{X(i)}{ }_{S}\right|}{\frac{1}{N} \sum_{i=0}^{N}\left|X(i)_{B}-\overline{X(i)}{ }_{B}\right|}\right] \times 100$

where $P$ is the percentage shown on the plots, $X(i)_{S}$ represents the anomalies from the 5-year mean for each year in the sensitivity runs (EmFix, MetFix, CldFix), and $X(i)_{B}$ is the same variable but for the BASE run. $N$ is the number of years considered (5 in this study).

Figure 7 shows a strong peak in the global ozone burden (+7\% in BASE for 1998) associated with the 1997-1998 El Niño event, a feature that agrees qualitatively with the findings of Zeng and Pyle (2005) (note that a direct quantitative comparison with the results of Zeng and Pyle (2005) would not be safe, since the tropopause definition that they use is different to what is used in the current manuscript). Table 3 shows the global annual budget terms for 1996-2000 as calculated in the BASE run. It is clear that the increased global tropospheric ozone abundances found in the 1997-1999 period are strongly related to increases in STE. Net chemical production is lower than average during these years and the deposition rate is larger, so changes in these terms are unlikely to have driven the ozone burden increases we find here. Note that, although STE is strongly influenced by meteorology, it can also be affected by emissions. This is because it can vary depending on the upper tropospheric ozone abundances, which are influenced by tropospheric chemistry, and, thus, by emissions.

Changes in meteorology have a stronger impact on global ozone than changes in emissions. The variability in the MetFix run is very small, and shows only a small increase in 1998 reflecting the intense wildfires. Meteorology drives almost $80 \%$ percent of the IAV of ozone on a global scale.

Clouds exert a smaller but non-negligible influence on the IAV of the ozone burdens. Globally they are responsible for $6 \%$ of the variability, which is around $8 \%$ of the total influence of changes in meteorology.

An examination of the importance of clouds and the rest of the factors in regional scales is presented next.

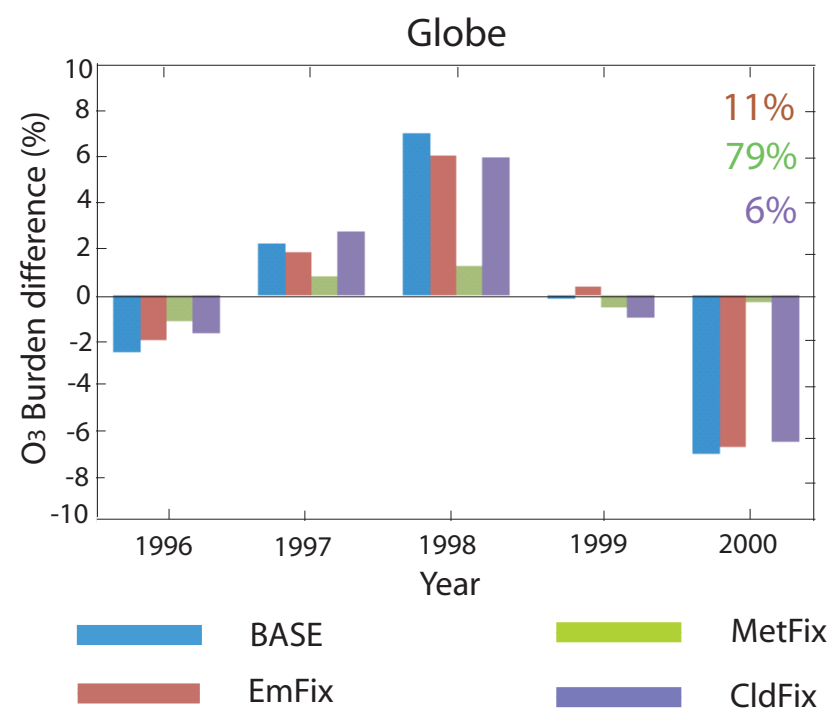

Fig. 7. Percentage global annual ozone burden differences from the 5-year mean as calculated from the four sensitivity runs: BASE (blue), EmFix (red), MetFix (green) and CldFix (purple). The numbers at the upper right part of the plot represent the amount of variability explained by each of the individual drivers: changing emissions (red - calculated from the difference between EmFix and BASE), changing meteorology (green - calculated from the difference between MetFix and BASE) and changing cloudiness (purple - calculated from the difference between CldFix and BASE).

\subsection{Regional scale analysis: Europe and Indonesia}

We focus here on Europe and Indonesia, representative of the northern extratropics and the tropics respectively, in order to examine how similar the responses of ozone, $\mathrm{CO}$ and $\mathrm{OH}$ are in these regions to year-to-year changes in emissions, meteorology and clouds.

\subsubsection{Tropospheric ozone IAV}

Figure 8 shows that there is a maximum in ozone burden over Europe in 1998 (in agreement with Koumoutsaris et al. (2008)), followed by a relative decline in 1999 and, especially, 2000. Meteorology is responsible for $86 \%$ of this variability while emissions changes are less important $(5 \%$ compared to $8 \%$ generally in the northern extratropics). Cloud changes drive $4 \%$ of the European ozone IAV. Over Indonesia, emissions drive a significant part of ozone IAV (32\%).

Table 4 shows the regional ozone budget terms for the BASE run over Europe and Indonesia. Europe is a net exporter of ozone for all the years of study $(-8$ to $-18 \mathrm{Tg} / \mathrm{yr})$, and we find a decrease in the net export of ozone from Europe in 1998-1999 (around 30\% less than average) which may reflect increased import or decreased export. Net chemistry (production minus loss) was lower than average during the same years and deposition was higher due to higher ozone concentrations, so the ozone peak is attributed to decreased 
Table 3. Global annual ozone budget terms for all the years of study (BASE run) and the 5-year mean. The transport term represents the STE for this global case.

\begin{tabular}{lrrrrrr}
\hline & 1996 & 1997 & 1998 & 1999 & 2000 & Mean \\
\hline Net Chemistry (Tg/year) & 658 & 581 & 380 & 466 & 662 & 549 \\
Transport (Tg/year) & 674 & 789 & 1012 & 859 & 627 & 792 \\
Deposition (Tg/year) & -1348 & -1374 & -1410 & -1364 & -1325 & -1364 \\
Burden $(T g)$ & 360 & 378 & 395 & 368 & 345 & 369 \\
\hline
\end{tabular}
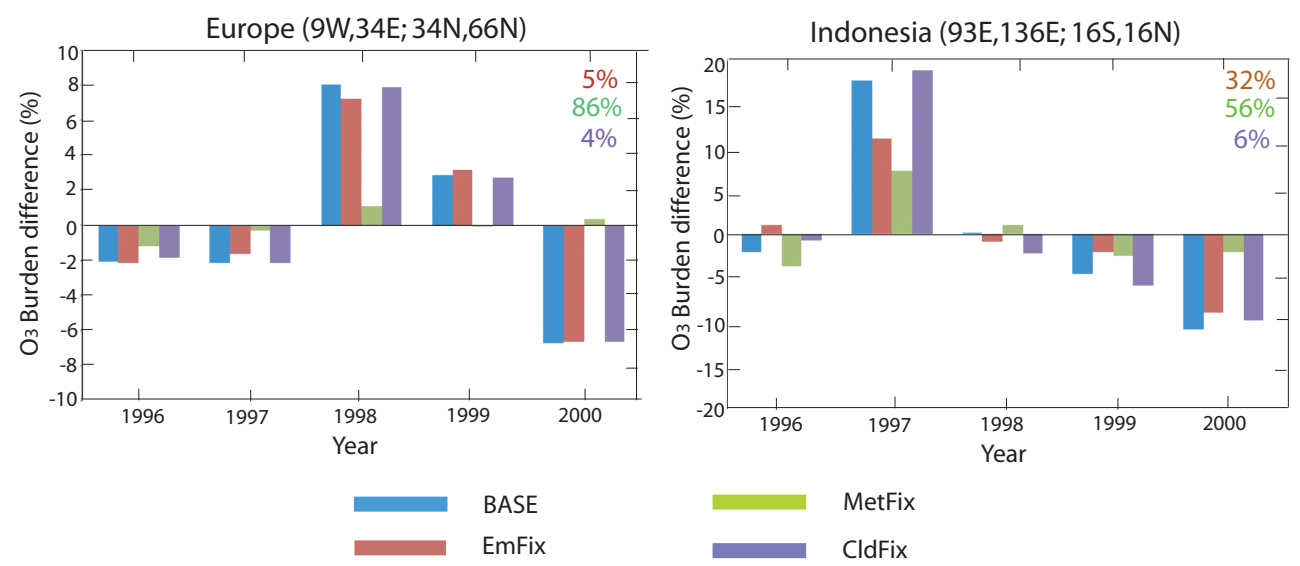

Fig. 8. Same as Fig. 7 but for the European and Indonesian boxes. Note the difference in the scale used for Indonesia ( -20 to $20 \%)$ due to the higher variability over this area.

Table 4. Regional annual ozone budget terms for the BASE run over Europe and Indonesia and the 5-year mean. The transport term relates both to STE and to transport processes within the troposphere to and from the regions.

\begin{tabular}{lrrrrrr}
\hline & 1996 & 1997 & 1998 & 1999 & 2000 & Mean \\
\hline EUROPE & & & & & & \\
Net Chemistry (Tg/year) & 76 & 74 & 66 & 67 & 75 & 72 \\
Transport (Tg/year) & -13 & -15 & -9 & -8 & -18 & -13 \\
Deposition (Tg/year) & -63 & -63 & -65 & -65 & -63 & -64 \\
Burden (Tg) & 8.4 & 8.4 & 9.3 & 8.8 & 9.0 & 8.6 \\
\hline INDONESIA & & & & & & \\
Net Chemistry (Tg/year) & 56 & 77 & 68 & 63 & 73 & 67 \\
Transport (Tg/year) & -29 & -32 & -45 & -32 & -42 & --36 \\
Deposition (Tg/year) & -37 & -47 & -37 & -35 & -35 & -38 \\
Burden (Tg) & 11.1 & 13.3 & 11.3 & 10.8 & 11.6 & 11.3 \\
\hline
\end{tabular}

net export. This decrease in net export may be a result of changes in the patterns of ozone production and loss or the dominance of transport regimes which do not favor export. Similarly, the ozone burden decrease over Europe in 2000 can be attributed to changes in net transport of ozone from the European region.

Over Indonesia, also a net exporter of ozone, the 1997 ozone burden maximum is caused by increased net chemistry but also by slightly lower than average net export from the region. This is most likely caused by subsidence of stratospheric ozone-rich air causing increased import of ozone. Horizontal transport to Indonesia within the troposphere was lower than average in 1997 due to strong low-level divergence. In 2000, the minimum ozone burden relates to the transport term being around $20 \%$ lower than average, indicating higher than average net export.

\subsubsection{Tropospheric $\mathrm{CO}$ and $\mathrm{OH}$ IAV}

Figure 9 shows the $\mathrm{CO}$ and $\mathrm{OH}$ results of the four runs (BASE, EmFix, MetFix and CldFix) for Europe and Indonesia. For $\mathrm{CO}$, clouds make a minor contribution, especially over Indonesia where only $1 \%$ of the IAV is explained by changes in cloudiness. Changes in meteorology are far less important than they are for ozone. Year-to-year variations in emissions explain 92\% of the IAV of CO over Indonesia and even over Europe, where biomass burning is not nearly so intense, this figure is as high as $82 \%$. These results contrast with those of Szopa et al. (2007), who found that in the tropics meteorology is the main reason driving CO IAV, while in the extratropics changes in emissions and meteorology are equally important. Differences in transport or chemical schemes, such as in the secondary production of $\mathrm{CO}$ from hydrocarbon oxidation, may partly explain these 

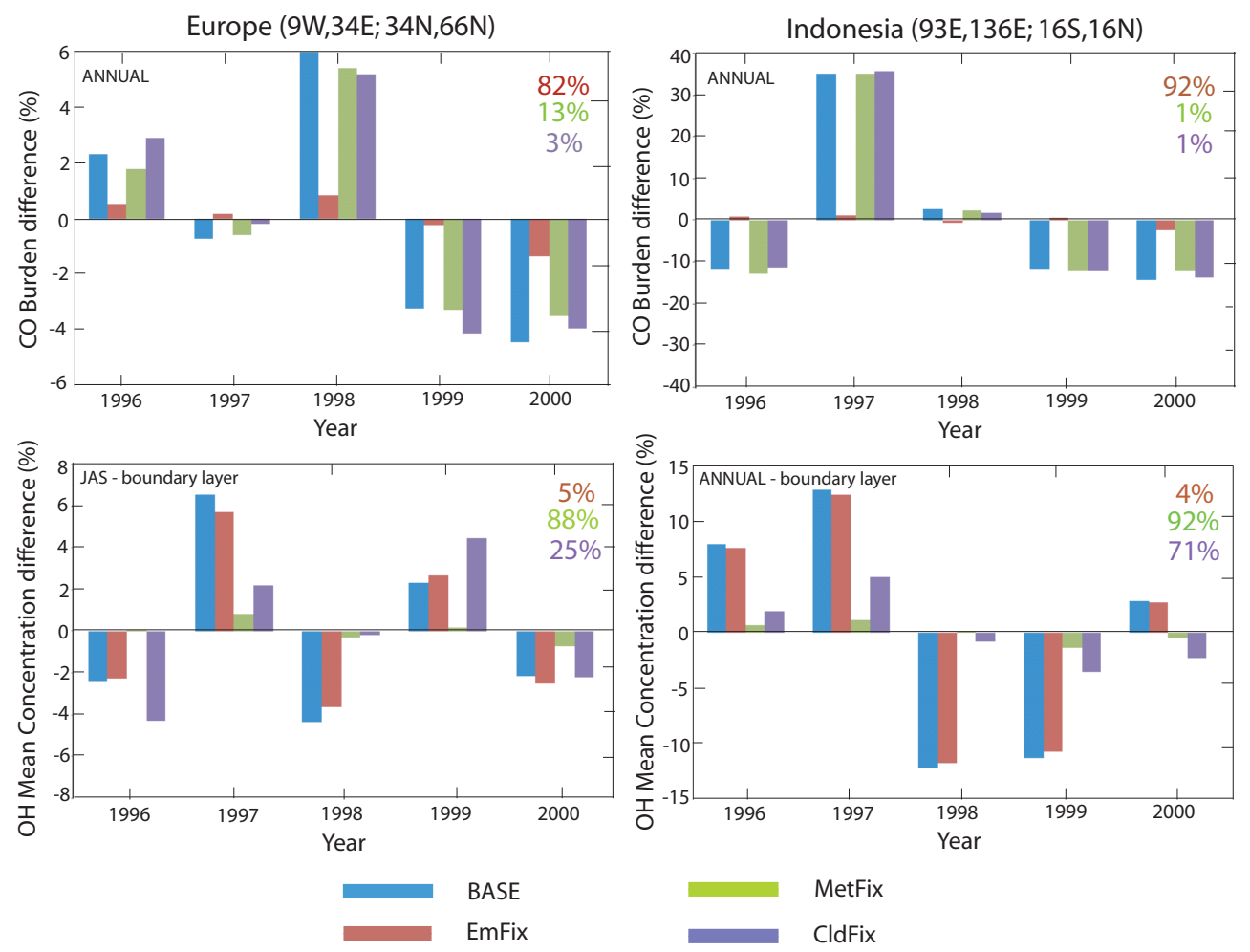

Fig. 9. Same as Fig. 8 but for $\mathrm{CO}$ and boundary layer $\mathrm{OH}$. For OH, July-August-September (JAS) means are examined over Europe while annual means are examined for Indonesia.

different results. A more important source of the differences may be that the current study focuses on regional pollutant burdens, while Szopa et al. (2007) examined individual surface stations, which are likely to be more greatly affected by small changes in meteorology.

The IAV of mass-weighted $\mathrm{OH}$ concentrations is examined in the bottom panels of Fig. 9. The analysis focuses on the boundary layer, where the impact of clouds is expected to be greatest. As shown by Voulgarakis et al. (2009b) and other previous studies, above and below-cloud modification of radiation is more important than in-cloud effects for $\mathrm{OH}$. For Europe, we present the results for summer (June-JulyAugust), as this is the season with the greatest solar radiation, when the impact of clouds on $\mathrm{OH}$ concentrations is highest. The figures show that when meteorology does not vary, almost none of the OH IAV is reproduced. This is consistent with Dentener et al. (2003), who found that IAV in $\mathrm{OH}$ is driven more strongly by meteorology than by surface emissions changes. It is clear that clouds are a very important component of this $\mathrm{OH}$ variability in the lower troposphere. $71 \%$ of the year-to-year variations in $\mathrm{OH}$ over Indonesia are caused by changes in cloudiness. Over Europe the figure is smaller (25\%) but still important. Thus, radiative cloud effects should not be ignored when studying the IAV of the tropospheric oxidizing capacity, especially since $\mathrm{OH}$ changes affect methane, a gas of major climate importance.
An OH minimum in $1998(-4 \%)$ over Europe can be partly explained by changes in cloudiness: it is less pronounced when fixing clouds and cloud optical depths are indeed lower than average in 1998 (not shown). The decrease of $\mathrm{OH}$ in 1998 could have been one of the causes of decreased net ozone chemistry over Europe in the same year shown in Table 4. By examining production and loss separately, we find increased ozone destruction in 1998 driven by higher ozone abundances, but also decreased ozone production, possibly due to lower $\mathrm{OH}$ and thus reduced peroxy radical concentrations. The effect of this is also boosted by the lower $\mathrm{NO}_{2}$ abundances in 1998 over much of Europe in the model (see Fig. 4).

Over Indonesia, cloud optical depths are mostly lower than average in 1997 (not shown), when the maximum OH concentrations are seen. This is related to the El Niño anomaly with less deep convection over a normally highly convective region. Although the area was dry during 1997, not favouring $\mathrm{OH}$ production, there was clearly a stronger influence by the higher photolysis rates due to fewer clouds. Higher ozone values (see Fig. 6) also contribute to the $\mathrm{OH}$ increase.

\section{Conclusions}

We have presented an assessment of how meteorology, emissions and clouds drive the interannual variability of important 
tropospheric tracers based on CTM calculations for the period 1996-2000. For $\mathrm{NO}_{2}$ and ozone, meteorology is the most important factor driving this variability for this period. On a global scale, around $80 \%$ of the ozone variability can be explained by changes in meteorological conditions (winds, humidity, clouds, temperatures). From our budget analysis and a consideration of the patterns of interannual variability of radon, we conclude that transport is most likely the strongest meteorology-related driver of year-to-year changes in ozone, both globally and, in the majority of cases, regionally. The effects of changing meteorology on STE are particularly important for driving many of these changes. A strong contribution from emissions variability is confined to areas where intense biomass burning occurs (e.g., Indonesia, Siberia). In contrast, emissions variability makes the largest contributions for $\mathrm{CO}$, both in the tropics and in the extratropics. For $\mathrm{OH}$, interannual variability is strongly driven by changes in meteorology and a particularly important component of this influence is the radiative effect of the variability in cloudiness.

A regional analysis reveals that the impact of meteorological variations on the modelled interannual variability in ozone is stronger than that of emission variations in both extratropical and tropical regions ( $86 \%$ of IAV driven by meteorology over Europe and 56\% over Indonesia). Clouds make a small but non-negligible contribution to the interannual variability of ozone. The interannual variability of $\mathrm{CO}$ shows no significant sensitivity to changes in clouds or meteorology over Indonesia. Over Europe, meteorology has a slightly greater effect, but remains a less important factor compared to emissions. However, the short lifetime of $\mathrm{OH}$ makes it susceptible to changes in clouds and to meteorology as a whole. Over Europe, cloud variability drives $25 \%$ of the interannual variability of $\mathrm{OH}$, while over Indonesia this figure is as high as $71 \%$. This suggests that future assessments of trends in tropospheric oxidizing capacity need to account for the interannual variation in cloudiness.

This study focuses on a single five-year period for analysis, and this may not be sufficiently long to avoid the influence of periodic meteorological features or isolated largescale individual events. However, we provide valuable conclusions on potential drivers of interannual variability to enhance our understanding of atmospheric composition changes, and suggest that future work should expand this discussion to longer timescales.

Acknowledgements. The authors wish to thank NERC and NCAS (UK), and IKY (Greece) for funding. A. V. thanks Paul Telford for useful suggestions on the data analysis methods. The authors thank Paul Berrisford for providing the ECMWF data. Emission datasets were obtained from the RETRO Project website (http: //retro.enes.org/). We also acknowledge the local staffs of the NyAlesund, Saturna, Zugspitze, Tsukuba, Izaña, Mauna Loa, Baltic Sea, Ulaan Uul, Ascension Island, Tutuila and Palmer Station measurement stations, as well as NOAA-ESRL-GMD and WDCGG.
Edited by: O. Cooper

\section{References}

Auvray, M. and Bey, I.: Long-range transport to Europe: Seasonal variations and implications for the European ozone budget, J. Geophys. Res., 110, D11303, doi:10.1029/2004JD005503, 2005.

Carver, G. D., Brown, P. D., and Wild, O.: The ASAD atmospheric chemistry integration package and chemical reaction database, Comput. Phys. Commun., 105, 197-215, 1997.

Chandra, S., Ziemke, J. R., Min, W., and Read, W. G.: Effects of 1997-1998 El Nino on tropospheric ozone and water vapor, Geophys. Res. Lett., 25, 3867-3870, 1998.

Cooper, O. R., Parrish, D. D., Stohl, A., Trainer, M., Nédélec, P., Thouret, V., Cammas, J. P., Oltmans, S. J., Johnson, B. J., Tarasick, D., Leblanc, T., McDermid, I. S., Jaffe, D., Gao, R., Stith, J., Ryerson, T., Aikin, K., Campos, T., Weinheimer, A., and Avery, M. A.: Increasing springtime ozone mixing ratios in the free troposphere over western North America, Nature, 463, 344-348, 2010.

Creilson, J. K., Fishman, J., and Wozniak, A. E.: Intercontinental transport of tropospheric ozone: a study of its seasonal variability across the North Atlantic utilizing tropospheric ozone residuals and its relationship to the North Atlantic Oscillation., Atmos. Chem. Phys., 3, 2053-2066, 2003,

http://www.atmos-chem-phys.net/3/2053/2003/.

Dalsoren, S. B. and Isaksen, I. S. A.: CTM study of changes in tropospheric hydroxyl distribution 1990-2001 and its impact on methane, Geophys. Res. Lett., 33, L23811, doi:10.1029/ 2006GL027295, 2006.

Dentener, F., Peters, W., Krol, M., van Weele, M., Bergamaschi, P., and Lelieveld, J.: Interannual variability and trend of $\mathrm{CH}_{4}$ lifetime as a measure for $\mathrm{OH}$ changes in the 1979-1993 time period, J. Geophys. Res., 108, 4442, doi:10.1029/2002JD002916, 2003.

Derwent, R. G., Stevenson, D. S., Collins, W. J., and Johnson, C. E.: Intercontinental transport and the origins of the ozone observed at surface sites in Europe, Atmos. Environ., 38, 18911901, 2004.

Doherty, R. M., Stevenson, D. S., Johnson, C. E., Collins, W. J., and Sanderson, M. G.: Tropospheric ozone and El Niño-Southern Oscillation: Influence of atmospheric dynamics, biomass burning emissions, and future climate change, J. Geophys. Res., 111, D19304, doi:10.1029/2005JD006849, 2006.

Duncan, B. N. and Bey, I.: A modeling study of the export pathways of pollution from Europe: Seasonal and interannual variations (1987-1997), J. Geophys. Res., 109, D08301, doi:10.1029/ 2003JD004079, 2004.

Duncan, B. N., Bey, I., Chin, M., Mickley, L. J., Fairlie, T. D., Martin, R. V., and Matsueda, H.: Indonesian wildfires of 1997: Impact on tropospheric chemistry, J. Geophys. Res., 108, 4458, doi:10.1029/2002JD003195, 2003.

Fowler, D., Coyle, M., ApSimon, H. M., Ashmore, M. R., Bareham, S. A., Battarbee, R. W., Derwent, R. G., Erisman, J. W., Goodwin, J., Grennfelt, P., Hornung, M., Irwin, J., Jenkins, A., Metcalfe, S. E., Ormerod, S. J., Reynolds, B., and Woodin, S.: Transboundary Air Pollution, Tech. rep., NEGTAP, 2001.

Hauglustaine, D., Brasseur, G.P., and Levine, J.: A sensitivity simulation of tropospheric ozone changes due to the 1997 Indonesian 
fire emissions, Geophys. Res. Lett., 26, 3305-3308, 1999.

Hess, P. G. and Mahowald, N.: Interannual variability in hindcasts of atmospheric chemistry: the role of meteorology, Atmos. Chem. Phys., 9, 5261-5280, 2009, http://www.atmos-chem-phys.net/9/5261/2009/.

Jacob, D. J., Prather, M. J., Rasch, P. J., Shia, R. L., Balkanski, Y. J., Beagley, S. R., Bergmann, D. J., Blackshear, W. T., Brown, M., Chiba, M., Chipperfield, M. P., deGrandpre, J., Dignon, J. E., Feichter, J., Genthon, C., Grose, W. L., Kasibhatla, P. S., Kohler, I., Kritz, M. A., Law, K., Penner, J. E., Ramonet, M., Reeves, C. E., Rotman, D. A., Stockwell, D. Z., VanVelthoven, P. F. J., Verver, G., Wild, O., Yang, H., and Zimmermann, P.: Evaluation and intercomparison of global atmospheric transport models using Rn-222 and other short-lived tracers, J. Geophys. Res., 102, 5953-5970, 1997.

Koumoutsaris, S., Bey, I., Generoso, S., and Thouret, V.: Influence of El Niño-Southern Oscillation on the interannual variability of tropospheric ozone in the northern midlatitudes, J. Geophys. Res., 113, D19301, doi:10.1029/2007JD009753, 2008.

Lathière, J., Hauglustaine, D. A., Friends, A. D., De NobletDucoudré, N., Viovy, N., and Folberth, G. A.: Impact of climate variability and land use changes on global biogenic volatile organic compound emissions, Atmos. Chem. Phys., 6, 2129-2146, 2006, http://www.atmos-chem-phys.net/6/2129/2006/.

Law, K. S. and Pyle, J. A.: Modeling trace gas budgets in the troposphere 1. Ozone and odd nitrogen, J. Geophys. Res., 98, 1837718400, 1993.

Li, Q. B., Jacob, D. J., Bey, I., Palmer, P. I., Duncan, B. N., Field, B. D., Martin, R. V., Fiore, A. M., Yantosca, R. M., Parrish, D. D., Simmonds, P. G., and Oltmans, S. J.: Transatlantic transport of pollution and its effects on surface ozone in Europe and North America, J. Geophys. Res., 107, 4166, doi: 10.1029/2001JD001422, 2002.

Liu, H., Crawford, J. H., Pierce, R. B., Norris, P., Platnick, S. E., Chen, G., Logan, J. A., Yantosca, R. M., Evans, M. J., Kittaka, C., Feng, Y., and Tie, X.: Radiative effect of clouds on tropospheric chemistry in a global three-dimensional chemical transport model, J. Geophys. Res., 111, D20303, doi:10.1029/ 2005JD006403, 2006.

Liu, J. F., Mauzerall, D. L., and Horowitz, L. W.: Analysis of seasonal and interannual variability in transpacific transport, J. Geophys. Res., 110, D04302, doi:10.1029/2004JD005207, 2005.

Moxim, W. J., Levy II, H., and Kasibhatla, P. S.: Simulated global tropospheric PAN: Its transport and impact on $\mathrm{NO}_{\mathrm{x}}$, J. Geophys. Res., 101, 12621-12638, 1996.

Müller, J.-F.: Geographical distribution and seasonal variation of surface emissions and deposition velocities of atmospheric trace gases, J. Geophys. Res., 97, 3787-3804, 1992.

Novelli, P. C., Masarie, K. A., Lang, P. M., Hall, B. D., Myers, R. C., and Elkins, J. W.: Reanalysis of tropospheric CO trends: Effects of the 1997-1998 wildfires, J. Geophys. Res., 108(D15), 4464, doi:10.1029/2002JD003031, 2003.

Oltmans, S. J. and Levy II, H.: Surface ozone measurements from a global network, Atmos. Environ., 28, 9-24, 1994.

Pfister, G., Pétron, G., Emmons, L. K., Gille, J. C., Edwards, D. P., Lamarque, J.-F., Attie, J.-L., Granier, C., and Novelli, P. C.: Evaluation of $\mathrm{CO}$ simulations and the analysis of the CO budget for Europe, J. Geophys. Res., 109, D19304, doi: 10.1029/2004JD004691, 2004.
Price, C. and Rind, D.: Modeling global lightning distributions in a General Circulation Model, Mon. Wea. Rev., 122, 1930-1939, 1994.

Richter, A., Burrows, J. P., Nuss, H., Granier, C., and Niemeier, U.: Increase in tropospheric nitrogen dioxide over China observed from space, Nature, 437, 129-132, 2005.

Savage, N. H., Pyle, J. A., Braesicke, P., Wittrock, F., Richter, A., Nüß, H., Burrows, J. P., Schultz, M. G., Pulles, T., and van het Bolscher, M.: The sensitivity of Western European $\mathrm{NO}_{2}$ columns to interannual variability of meteorology and emissions: a model - GOME study, Atmos. Sci. Lett., 9(4), 182-188, doi:10.1002/ asl.193, 2008.

Schultz, M. G.: Emission data sets and methodologies for estimating emissions, RETRO deliverable D1-6, Tech. rep., 5th EU framework programme, 2007.

Shindell, D. T., Faluvegi, G., Stevenson, D. S., Krol, M. C., Emmons, L. K., Lamarque, J.-F., Pétron, G., Dentener, F. J., Ellingsne, K., Schultz, M. G., Wild, O., Amann, M., Atherton, C. S., Bergmann, D. J., Bey, I., Butler, T., Cofala, J., Collins, W. J., Derwent, R. G., Doherty, R. M., Drevet, J., Eskes, H. J., Fiore, A. M., Gauss, M., Hauglustaine, D. A., Horowitz, L. W., Isaksen, I. S. A., Lawrence, M. G., Montanaro, V., Müller, J.-F., Pitari, G., Prather, M. J., Pyle, J. A., Rast, S., Rodriguez, J. M., Sanderson, M. G., Savage, N. H., Strahan, S. E., Sudo, K., Szopa, S., Unger, N., van Noije, T. P. C., and Zeng, G.: Multimodel simulations of carbon monoxide: Comparison with observations and projected near-future changes, J. Geophys. Res., 111, D19306, doi:10.1029/2006JD007100, 2006.

Spichtinger, N., Damoah, R., Eckhardt, S., Forster, C., James, P., Beirle, S., Marbach, T., Wagner, T., Novelli, P. C., and Stohl, A.: Boreal forest fires in 1997 and 1998: a seasonal comparison using transport model simulations and measurement data, Atmos. Chem. Phys., 4, 1857-1868, 2004,

http://www.atmos-chem-phys.net/4/1857/2004/.

Stevenson, D. S., Dentener, F. J., Schultz, M. G., Ellingsen, K., van Noije, T. P. C., Wild, O., Zeng, G., Amann, M., Atherton, M., Bell, N., Bergmann, D. J., Bey, I., Bulter, T., Cofala, J., Collins, W. J., Derwent, R. G., Doherty, R. M., Drevet, J., Eskes, H. J., Fiore, A. M., Gauss, M., Hauglustaine, D. A., Horowitz, L. W., Isaksen, I. S. A., Krol, M. C., Lamarque, J.-F., Lawrence, M. G., Montanaro, V., Müller, J. F., Pitari, G., Prather, M. J., Pyle, J. A., Rast, S., Rodriguez, J. M., Sanderson, M. G., Savage, N. H., Shindell, D. T., Strahan, S. E., Sudo, K., and Szopa, S.: Multimodel ensemble simulations of present-day and nearfuture tropospheric ozone, J. Geophys. Res., 111, D08301, doi: 10.1029/2005JD006338, 2006.

Stockwell, D. Z., Giannakopoulos, C., Plantevin, P.-H., Carver, G. D., Chipperfield, M. P., Law, K. S., Pyle, J. A., Shallcross, D. E., and Wang, K. Y.: Modelling $\mathrm{NO}_{\mathrm{x}}$ from lightning and its impact on global chemical fields, Atmos. Environ., 33, 44774493, 1999.

Sudo, K. and Takahashi, M.: Simulation of tropospheric ozone changes during 1997-1998 El Nino: Meteorological impact on tropospheric photochemistry, Geophys. Res. Lett., 28, 40914094, 2001.

Szopa, S., Hauglustaine, D. A., and Ciais, P.: Relative contributions of biomass burning emissions and atmospheric transport to carbon monoxide interannual variability, Geophys. Res. Lett., 34, L18810, doi:10.1029/2007GL030231, 2007. 
Telford, P. J., Lathièire, J., Abraham, N. L., Braesicke, P., Johnson, C. E., Morgenstern, O., O'Connor, F. M., Pike, R. C., Wild, O., Young, P. J., Beerling, D., Hewitt, C. N., and Pyle, J.: Effects of climate-induced changes in isoprene emissions after the eruption of Mount Pinatubo, Atmos. Chem. Phys. Discuss., submitted, 2009.

Thouret, V., Cammas, J. P., Sauvage, B., Athier, G., Zbinden, R., Nedeleck, P., Simon, P., and Karcher, F.: Tropopause referenced ozone climatology and inter-annual variability (1994-2003) from the MOZAIC programme, Atmos. Chem. Phys., 6, 1033-1051, 2006, http://www.atmos-chem-phys.net/6/1033/2006/.

Tie, X. X., Madronich, S., Walters, S., Y., Z. R., Rasch, P., and Collins, W.: Effect of clouds on photolysis and oxidants in the troposphere, J. Geophys. Res., 108(D20), 4642, doi:10.1029/ 2003JD003659, 2003.

Uno, I., He, Y., Ohara, T., Yamaji, K., Kurokawa, J. I., Katayama, M., Wang, Z., Noguchi, K., Hayashida, S., Richter, A., and Burrows, J. P.: Systematic analysis of interannual and seasonal variations of model-simulated tropospheric $\mathrm{NO}_{2}$ in Asia and comparison with GOME-satellite data, Atmos. Chem. Phys., 7, 16711681, 2007, http://www.atmos-chem-phys.net/7/1671/2007/.

van Noije, T. P. C., Eskes, H. J., Dentener, F. J., Stevenson, D. S., Ellingsen, K., Schultz, M. G., Wild, O., Amann, M., Atherton, C. S., Bergmann, D. J., Bey, I., Boersma, K. F., Butler, T., Cofala, J., Drevet, J., Fiore, A. M., Gauss, M., Hauglustaine, D. A., Horowitz, L. W., Isaksen, I. S. A., Krol, M. C., Lamarque, J.-F., Lawrence, M. G., Martin, R. V., Montanaro, V., Muller, J. F., Pitari, G., Prather, M. J., Pyle, J. A., Richter, A., Rodriguez, J. M., Savage, N. H., Strahan, S. E., Sudo, K., Szopa, S., and van Roozendael, M.: Multi-model ensemble simulations of tropospheric $\mathrm{NO}_{2}$ compared with GOME retrievals for the year 2000, Atmos. Chem. Phys., 6, 2943-2979, 2006,

http://www.atmos-chem-phys.net/6/2943/2006/.
Voulgarakis, A., Savage, N. S., Wild, O., Carver, G. D., Clemithsaw, K. C., and Pyle, J. A.: Upgarding photolysis in the p-TOMCAT CTM: model evaluation and assessment of the role of clouds, Geosci. Mod. Devel., 2, 59-72, 2009a.

Voulgarakis, A., Wild, O., Carver, G. D., Savage, N. S., and Pyle, J. A.: Clouds, photolysis and global and regional tropospheric ozone budgets, Atmos. Chem. Phys., 9, 8235-8246, 2009 b.

Wild, O. and Akimoto, H.: Intercontinental transport of ozone and its precursors in a three-dimensional global CTM, J. Geophys. Res., 106, 27729-27744, 2001.

Wild, O., Zhu, X., and Prather, M. J.: Fast-J: Accurate simulation of in- and below-cloud photolysis in Global Chemical Models, J. Atmos. Chem., 37, 245-282, 2000.

Zeng, G. and Pyle, J. A.: Influence of El Niño Southern Oscillation on stratosphere/troposphere exchange and the global tropospheric ozone budget, Geophys. Res. Lett., 32, L01814, doi: 10.1029/2004GL021353, 2005. 